\title{
Respiratory function and symptoms in workers exposed simultaneously to jute and hemp
}

\author{
S. H. EL GHAWABI \\ From the National Institute of Occupational Safety and Health, Heliopolis, Cairo
}

ABSTRACT The environment and health of a working population exposed simultaneously to jute and hemp were studied. Classical symptoms of byssinosis were not present but 21 workers $(7 \%)$ complained of atypical tightness of the chest. The prevalence of chronic bronchitis among the exposed workers was statistically significant in comparison with controls. Effects of dust concentrations, age and duration of exposure on the prevalence of chronic bronchitis were studied. A statistically significant reduction in $\mathrm{FEV}_{\mathbf{1 . 0}}$ at the end of a work shift occurred in all the exposed workers. Bronchodilators given after the shift showed that acute reductions in forced expiratory volumes were nearly fully reversible in all exposed workers. Smokers and those with chronic bronchitis had greater reductions in $\mathrm{FEV}_{1 \cdot 0}$ values at the end of the work shift.

Jute is, by volume, the second largest natural textile fibre processed in Egypt (Central Agency for Public Mobilization and Statistics, 1974). It is used mainly for products in which low cost is more important than strength and durability. Jute fibres may be used on their own, or blended with other natural fibres such as kenaf (hemp) (Hibiscus Cannabinus) of the Malvaceae family. The majority of previous investigators have studied the effects of these vegetable dusts as though each type occurs in isolation. Thus, byssinosis has been described as occurring in some exposed workers as a result of hemp processing (Bouhuys et al., 1967; Valić et al., 1968; Valić and Žuškin, 1972). On the other hand, apart from Popa et al. (1969), no-one has reported byssinosis from jute processing (Schilling, 1956; Mair et al., 1960; Siddhu et al., 1966; Valić and Žuškin, 1971). Normal occupational exposure is to mixtures of fibres rather than to a single type, but there are few reports describing the effects of such mixtures. Smith et al. (1969) and Žuškin and Valić (1973) reported the effects of simultaneous exposure to flax and hemp dusts. However, the combined effects of jute and hemp exposure have not been reported in the literature so far. The following is a survey of respiratory symptoms together with measurements of ventilatory function in workers exposed simul-

Received for publication 15 March 1977

Accepted for publication 7 June 1977 taneously to imported jute and Egyptian hemp in one of the two largest jute-processing factories in Egypt.

\section{Methods}

After excluding seven workers with tuberculosis and three workers with heart disease, a total of 311 male workers in the batting, hackling, carding and drawing sections were interviewed. Details of the present and past medical and occupational histories were obtained. An adaptation of the British Medical Research Council Questionnaire on respiratory symptoms with additional questions on byssinosis (Schilling et al., 1964), was used by our interviewers. Chronic bronchitis and asthma were defined according to the Ciba Guest Symposium (1959). Other respiratory symptoms (ORS) were defined as upper respiratory symptoms not satisfying the criteria for the diagnosis of chronic bronchitis, such as frequent nasal catarrh, sinusitis and unproductive cough. After two practice recordings, a nine-litre Palmer spirometer was used to make three recordings of the forced expiratory spirogram with the subject sitting down, before and after the Saturday and Thursday work shifts. The forced expiratory volume in one second $\left(F V_{1.0}\right)$ was calculated from these tracings. The maximum of the three readings was taken, and converted according to body temperature and saturation water vapour pressure. The measurements were also repeated at the end of a work shift after the subject had taken three puffs of a bron- 
chodilator (Salbutamol) from a pocket nebuliser (Ventolin inhaler). The degree of reversibility of the reduced ventilatory capacity was determined 15 minutes after inhalation of the bronchodilator. A control group of 50 workers of similar age and socioeconomic standard to the study group was chosen from the general service workers (caretakers, outdoor erection and restaurant workers) who had not been exposed to any dusty working atmosphere.

Dust samples were collected for gravimetric determination of respirable particles using a Hexhlet sampler at a constant flow rate of $50 \mathrm{l} / \mathrm{min}$ for 30 min. Total dust was collected on membrane filters mounted on vertical holders adjusted to obtain samples from the workers' breathing zones. Eighteen dust samples were collected from every workplace for examination of both respirable and total dust.

\section{Results}

Table 1 shows the distribution of workers according to type of work, age range and duration of exposure. The age range was 21-57 yr with a mean of $36.7 \mathrm{yr}$ $( \pm 9 \cdot 1)$, while the mean age for the control group was $37 \cdot 2$ yr $( \pm 8 \cdot 6)$. The difference between the two means was not statistically significant $(P>0 \cdot 1)$. The age distribution of all exposed workers in relation to the duration of exposure is given in Table 2. It was found that $34 \%$ of the exposed workers were under 30 years of age; $30 \%$ between 30 and $39 ; 20 \%$ in the fifth decade and $16 \% 50$ years old or over. The duration of exposure varied from less than five years in 63 workers $(20 \%)$; five to nine years in 91 workers $(29 \%) ; 10-14$ yr in 101 workers $(33 \%)$ and more than $15 \mathrm{yr}$ in 56 workers $(18 \%)$.

Table 3 gives the smoking status of the men in both the exposed and control groups. As the number of ex-smokers was found to be too small for valid statistical analysis, they were added to the group of non-smokers. The difference between both the exposed workers and controls as regards smoking was not statistically significant $(P>0 \cdot 1)$.

In the exposed group, no workers reported symptoms of classical byssinotic tightness (Table 4). However, 21 workers $(7 \%)$ did suffer from tightness of the chest, but this bore no relation to the first day of the working week. Such atypical tightness tended to occur after a variable period from the start of the work shift, lasting a few minutes and relieved by fresh air. At a later stage it lasted throughout all or the rest of the shift and necessitated the use of bronchodilators. The prevalence did not increase significantly with length of exposure $(0.1>\mathrm{P}>0.05$, Table 5) and was not significantly correlated with dust concentration (Table 7). Such chest tightness is similar to that previously described by El Sobkey (1975) in cotton textile workers although in his subjects the prevalence of this tightness was significantly increased in more dusty occupations.

Table 2 Distribution of exposed workers according to age and period of exposure

\begin{tabular}{llllll}
\hline $\begin{array}{l}\text { Age range } \\
(y r)\end{array}$ & $\begin{array}{l}\text { No. of } \\
\text { workers }\end{array}$ & \multicolumn{5}{l}{\begin{tabular}{l} 
Period of exposure $(y r)$ \\
\cline { 2 - 6 }
\end{tabular}} & & $<5$ & $5-9$ & $10-14$ & $15+$ \\
\hline $20-29$ & 107 & 52 & 39 & 14 & 2 \\
$30-39$ & 92 & 9 & 41 & 36 & 6 \\
$40-49$ & 65 & 1 & 9 & 34 & 21 \\
$50+$ & 47 & 1 & 2 & 17 & 27 \\
Total & 311 & 63 & 91 & 101 & 56 \\
\hline
\end{tabular}

Table 3 Smoking status of exposed and control workers

\begin{tabular}{|c|c|c|c|c|}
\hline \multirow{2}{*}{$\begin{array}{l}\text { Smoking } \\
\text { status }\end{array}$} & \multicolumn{2}{|c|}{ Exposed workers } & \multicolumn{2}{|c|}{ Controls } \\
\hline & No. & $\%$ & No. & $\%$ \\
\hline $\begin{array}{l}\text { Smokers } \\
\text { Non-smokers } \\
\text { Total }\end{array}$ & $\begin{array}{l}152 \\
159 \\
311\end{array}$ & $\begin{array}{l}49 \\
51\end{array}$ & $\begin{array}{l}23 \\
27 \\
50\end{array}$ & $\begin{array}{l}46 \\
54\end{array}$ \\
\hline
\end{tabular}

Table 4 Prevalence of respiratory symptoms in exposed workers and controls

\begin{tabular}{|c|c|c|c|c|c|}
\hline \multirow[t]{2}{*}{ Symptom } & \multicolumn{2}{|c|}{ Exposed workers } & \multicolumn{2}{|c|}{ Controls } & \multirow[t]{2}{*}{$\boldsymbol{P}$} \\
\hline & No. & $\%$ & No. & $\%$ & \\
\hline Byssinosis & - & 0 & - & $\mathbf{0}$ & - \\
\hline $\begin{array}{l}\text { Atypical chest } \\
\text { tightness }\end{array}$ & 21 & 7 & - & 0 & 0.0093 \\
\hline Chronic bronchitis & 66 & 21 & $\begin{array}{l}3 \\
2\end{array}$ & 6 & 0.0002 \\
\hline $\begin{array}{l}\text { Bronchial asthma } \\
\text { Other respiratory }\end{array}$ & $\begin{array}{l}12 \\
22\end{array}$ & $\begin{array}{l}4 \\
7\end{array}$ & $\begin{array}{l}2 \\
1\end{array}$ & $\begin{array}{l}4 \\
2\end{array}$ & $\begin{array}{l}\text { ns } \\
0.05\end{array}$ \\
\hline
\end{tabular}

ns $=$ not significant

Table 1 Distribution of exposed workers according to type of work, age range and period of exposure

\begin{tabular}{|c|c|c|c|c|c|c|c|c|c|}
\hline \multirow[t]{2}{*}{ Type of work } & \multirow[t]{2}{*}{ No. of workers } & \multicolumn{4}{|c|}{ Age range $(y r)$} & \multicolumn{4}{|c|}{ Period of exposure (yr) } \\
\hline & & $20-29$ & $30-39$ & $40-49$ & $50+$ & $<5$ & $5-9$ & $10-14$ & $15+$ \\
\hline $\begin{array}{l}\text { Batting } \\
\text { Hackling } \\
\text { Carding } \\
\text { Drawing }\end{array}$ & $\begin{array}{r}18 \\
72 \\
139 \\
82\end{array}$ & $\begin{array}{r}3 \\
26 \\
45 \\
33\end{array}$ & $\begin{array}{r}5 \\
28 \\
42 \\
17\end{array}$ & $\begin{array}{r}6 \\
10 \\
31 \\
18\end{array}$ & $\begin{array}{r}4 \\
8 \\
21 \\
14\end{array}$ & $\begin{array}{r}2 \\
5 \\
31 \\
25\end{array}$ & $\begin{array}{r}5 \\
19 \\
49 \\
18\end{array}$ & $\begin{array}{r}7 \\
29 \\
39 \\
26\end{array}$ & $\begin{array}{r}4 \\
19 \\
20 \\
13\end{array}$ \\
\hline Total & 311 & 107 & 92 & 65 & 47 & 63 & 91 & 101 & 56 \\
\hline
\end{tabular}


Table 5 Chronic bronchitis and atypical chest tightness according to length of exposure

\begin{tabular}{llcclc}
\hline $\begin{array}{l}\text { Length of } \\
\text { exposure } \\
\text { (yr) }\end{array}$ & $\begin{array}{l}\text { No. of } \\
\text { workers }\end{array}$ & \multicolumn{2}{c}{ Chronic bronchitis } & \multicolumn{2}{l}{ Atypical chest tightness } \\
\cline { 3 - 6 } & & No. & $\%$ & No. & $\%$ \\
\hline$<5$ & 63 & 5 & 8 & 1 & 2 \\
$5-9$ & 91 & 15 & 16 & 5 & 5 \\
$10-14$ & 101 & 24 & 24 & 8 & 8 \\
$15+$ & 56 & 22 & 39 & 7 & 12 \\
\hline
\end{tabular}

$\chi^{2}$ with 3 degrees of freedom $=19.88$ calculated for the prevalence of chronic bronchitis according to the duration of exposure $(P<0.005)$; for atypical tightness according to the period of exposure $x^{2}=6.66$ $(0.1>$ P $>0.05)$.

Table 6 Chronic bronchitis in exposed workers and controls according to smoking status

\begin{tabular}{lrrr}
\hline Smoking & No. of workers & \multicolumn{2}{l}{ Chronic bronchitis } \\
\cline { 3 - 4 } category & & No. & $\%$ \\
\hline Smokers & & & \\
Exposed & 152 & 35 & 23.0 \\
Controls & 23 & 2 & 9.0 \\
Non-smokers & & 31 & 19.0 \\
Exposed & 159 & 1 & 4.0 \\
Controls & 27 & 27 & \\
\hline
\end{tabular}

It was found that 66 exposed workers $(21 \%)$ had chronic bronchitis, which occurred in only $6 \%$ of the control group. This difference in prevalence between the two groups was statistically significant $(P<$ 0.0002). The difference in smoking status between exposed and control subjects is shown in Table 6. Exposure to a mixture of vegetable dusts appeared to be a more important factor than smoking in the aetiology of chronic bronchitis.

There was a highly significant increase in the prevalence of chronic bronchitis in the more dusty atmospheres compared with the less dusty work places (39\% and $40 \%$ in the batting and hackling sections respectively, while its prevalence was $16 \%$ among carders and $10 \%$ among drawers), (Table 7). The prevalence of chronic bronchitis increased steeply with age and this was particularly marked among workers over 50 years old (Table 8). Moreover, the prevalence of chronic bronchitis in exposed workers increased with increasing duration of employment (length of exposure, Table 5).

Further analysis of these results, taking age and duration of exposure into account, showed a significant relationship between the prevalence of chronic bronchitis and duration of exposure in two groups of workers, those aged 20-29 yr, and those over 50 yr. However, this relationship was not statistically significant in the age ranges $30-39$ and 40$49 \mathrm{yr}$. This could be explained by the fact that young people may be highly physically active in the course of their work, which consequently increases lung ventilation. It is known that chronic respiratory disease are more common in old age in those generally exposed to atmospheric pollution, and to industrial pollution in particular.

\section{PULMONARY FUNCTION TESTS}

Changes in FEV 1.0 in exposed workers who did, or who did not, use the bronchodilator at the end of the work shift are shown in Table 9. It is apparent that exposure to a mixture of jute and hemp dust was associated with a statistically significant fall in FEV 1.0 during the first working day, $(t=12.5, \mathrm{P}<0.001)$. This reduction tended to be maintained throughout the week and no further significant decrease was observed during exposure on Thursday. Administration of the bronchodilator after the shift showed that marked reduction in ventilatory capacity was almost fully reversible in all the workers.

Table 8 Chronic bronchitis according to age group and smoking category in exposed workers

\begin{tabular}{llrrr}
\hline \begin{tabular}{l} 
Smoking $\begin{array}{l}\text { S } \\
\text { category }\end{array}$ \\
\cline { 2 - 5 }
\end{tabular} & \multicolumn{4}{l}{$\begin{array}{l}\text { Number and percentage of workers with chronic bronchitis } \\
\text { at ages }(y r)\end{array}$} \\
\cline { 2 - 5 } $20-29$ & $30-39$ & $40-49$ & $50+$ \\
\hline Smokers & $6(12 \%)$ & $9(21 \%)$ & $9(26 \%)$ & $11(50 \%)$ \\
Non-smokers $4(7 \%)$ & $8(16 \%)$ & $7(14 \%)$ & $12(48 \%)$ \\
Smokers and $10(9 \%)$ & $17(18 \%)$ & $16(26 \%)$ & $23(49 \%)$ \\
non-smokers & & & & \\
\hline
\end{tabular}

$\chi^{2}$ with 3 degrees of freedom $=31.97$ for the whole group (smokers and non-smokers); $P<0.005$.

Table 7 Chronic bronchitis and atypical chest tightness in exposed workers according to type of work

\begin{tabular}{|c|c|c|c|c|c|c|c|c|c|}
\hline \multirow[t]{2}{*}{ Type of work } & \multirow[t]{2}{*}{ No. of workers } & \multicolumn{2}{|c|}{$\begin{array}{l}\text { Total dust } \\
\left(\mathrm{mg} / \mathrm{m}^{3}\right)\end{array}$} & \multicolumn{2}{|c|}{$\begin{array}{l}\text { Respirable dust } \\
\left(\mathrm{mg} / \mathrm{m}^{3}\right)\end{array}$} & \multicolumn{2}{|c|}{ Chronic bronchitis } & \multicolumn{2}{|c|}{ Atypical chest tightness } \\
\hline & & Mean & $S D$ & Mean & $S D$ & No. & $\%$ & No. & $\%$ \\
\hline $\begin{array}{l}\text { Batting } \\
\text { Hackling } \\
\text { Carding } \\
\text { Drawing }\end{array}$ & $\begin{array}{r}18 \\
72 \\
139 \\
82\end{array}$ & $\begin{array}{c}110 \cdot 23 \\
114 \cdot 61 \\
36 \cdot 49 \\
3 \cdot 2\end{array}$ & $\begin{array}{c}12 \cdot 42 \\
13 \cdot 61 \\
6 \cdot 8 \\
0.9\end{array}$ & $\begin{array}{r}30.2 \\
32 \cdot 6 \\
4.9 \\
0.8\end{array}$ & $\begin{array}{l}7.8 \\
8 \cdot 6 \\
1 \cdot 1 \\
0.5\end{array}$ & $\begin{array}{r}7 \\
29 \\
22 \\
8\end{array}$ & $\begin{array}{l}39 \\
40 \\
16 \\
10\end{array}$ & $\begin{array}{l}1 \\
5 \\
9 \\
6\end{array}$ & $\begin{array}{l}6 \\
7 \\
6 \\
7\end{array}$ \\
\hline
\end{tabular}

$x^{2}$ with 3 degrees of freedom $=26.4$ calculated for the prevalence of chronic bronchitis according to the degree of dustiness (P $<0.005$ ); for atypical tightness $x^{2}$ was not significant. 
Closer analysis of the pulmonary function data showed that smokers and those with bronchitis have greater reductions in forced expiratory volumes at the end of the work shift than do other workers (Table 10). The decrease in $\mathrm{FEV}_{1.0}$ was $196 \mathrm{ml}$ in smokers compared with $118 \mathrm{ml}$ in non-smokers. In exposed men with chronic bronchitis the mean decrease in FEV $_{1.0}$ was $236 \mathrm{ml}$ compared with $135 \mathrm{ml}$ in the nonbronchitics. The fall in FEV 1.0 was not found to be significantly correlated with differences in the type of work (Table 11). Thus it was concluded that there was no correlation between the concentration of dust inhaled and impairment of ventilatory function. Moreover, the changes in $\mathrm{FEV}_{1.0}$ with age were not statistically significant (Table 12). On the other hand, changes in $\mathrm{FEV}_{1.0}$ according to duration of occupational exposure were significant at the $5 \%$ level (Table 13).

\section{Discussion}

There is no doubt that exposure to a high concentration of mixed jute and hemp dust represents an occupational health hazard. It caused an acute reduction in ventilatory capacity during the shift,

Table $9 F E V_{1.0}$ reduction at the end of a work shift in exposed workers compared with controls

\begin{tabular}{|c|c|c|c|c|c|}
\hline \multirow{3}{*}{$\begin{array}{l}\text { Bronchodilator } \\
\text { used }\end{array}$} & \multicolumn{5}{|c|}{ Reduction in FEV $V_{1.0}$ in $m l$ at end of work shift } \\
\hline & \multicolumn{2}{|c|}{ Exposed workers } & \multicolumn{2}{|c|}{ Controls } & \multirow[t]{2}{*}{$P$} \\
\hline & Range & Mean & Range & Mean & \\
\hline $\begin{array}{l}\text { No } \\
\text { Yes }\end{array}$ & $\begin{array}{c}40-300 \\
0-50\end{array}$ & $\begin{array}{r}156 \\
23\end{array}$ & $\begin{array}{l}0-100 \\
0-30\end{array}$ & $\begin{array}{l}35 \\
13\end{array}$ & $\begin{array}{l}<0.001 \\
>0.1\end{array}$ \\
\hline
\end{tabular}

Table 10 Mean reduction in FEV $V_{1 \cdot 0}$ in exposed workers according to smoking status and presence or absence of chronic bronchitis

\begin{tabular}{lcll}
\hline Category & $\begin{array}{l}\text { No. of } \\
\text { workers }\end{array}$ & $\begin{array}{l}\text { Mean } \\
\text { reduction in } \\
F E V_{1.0}(m l)\end{array}$ & $P$ \\
\hline Smokers & 152 & 196 & $<0.001$ \\
Non-smokers & 159 & 118 & $<0.001$ \\
With chronic bronchitis & 66 & 236 & \\
Without chronic bronchitis 245 & 135 & \\
\hline
\end{tabular}

Table 11 Mean reduction in FEV $V_{1 \cdot 0}$ at the end of a work shift in relation to dust inhaled because of type of work

\begin{tabular}{lcl}
\hline Type of work & No. of workers & $\begin{array}{l}\text { Mean reduction in } \\
\text { FEV } V_{1.0} \text { at end of work } \\
\text { shift }(\mathrm{ml})\end{array}$ \\
\hline Batting & 18 & 157 \\
Hackling & 72 & 156 \\
Carding & 139 & 156 \\
Drawing & 82 & 158 \\
\hline
\end{tabular}

Table 12 Mean reduction in $F E V_{1.0}$ at the end of $a$ work shift according to the age ranges of exposed workers

\begin{tabular}{lll}
\hline Age range $(y r)$ & No. of workers & $\begin{array}{l}\text { Mean reduction in } \\
\text { FEV }\end{array}$ \\
shift $(\mathrm{ml})$
\end{tabular}

Table 13 Mean reduction in $F E V_{1 \cdot 0}$ at the end of a work shift according to the period of occupational exposure of the workers

\begin{tabular}{lll}
\hline $\begin{array}{l}\text { Duration of exposure } \\
(y r)\end{array}$ & No. of workers & $\begin{array}{l}\text { Mean reduction in } \\
F E V_{1.0} \text { at end of work } \\
\text { shift }(\mathrm{ml})\end{array}$ \\
\hline$<5$ & & 143 \\
$5-9$ & 63 & 156 \\
$10-14$ & 91 & 162 \\
$15+$ & 101 & 162 \\
\hline
\end{tabular}

that was considerably more pronounced in those who had chronic bronchitis. Such changes could not be attributed to diurnal variation which, if it occurs, is usually in the opposite direction. Moreover, in the conditions described here, this exposure did not induce typical byssinosis, but did lead to the development of chronic respiratory impairment.

The overall picture of byssinosis in Egypt is still uncertain. Although many investigators, following El Batawi (1962), found a high prevalence of byssinosis in cotton and flax workers, other workers, such as El Sobkey (1975), did not encounter byssinosis in their field studies. The Ministry of Manpower has not registered any byssinotic cases for compensation, apart from one very recent example in Tanta Textile Mill. This can be explained by the fact that the physicians of the Ministry of Manpower and Social Security Organization diagnose byssinosis according to the criteria defined by Taylor and Massoud (1968). All the cases referred were refused compensation because they did not satisfy such criteria. El Batawi (1969) has admitted that, in his previous studies, he found it difficult to fit the cases seen into the classification proposed. This was particularly so in grade $\frac{1}{2}$ and grade 2 where the signs and symptoms actually observed were classified on the assumption that these grades were the nearest possible to the actual findings. He considered that the classification of byssinosis proposed by Roach and Schilling (1960) may not always be applicable except perhaps in British circumstances where there are additional factors involved that may not exist in other countries such as Egypt, India, the United States of America and the Philippines. 
We wish to thank Dr Guirguis A. Ibrahim, Moustapha F. Gaber and Nawal Maymoon for their assistance with the pulmonary function tests, and also Shazia Y. Gaafar and Haney N. Iskander who helped us by measuring the dusts to which the workers were exposed.

\section{References}

Bouhuys, A., Barbero, A., Lindell, S. E., Roach, S. A., and Schilling, R. S. F. (1967). Byssinosis in hemp workers. Archives of Environmental Health, 14, 533-544.

Bouhuys, A., Gilson, J. G., and Schilling, R. S. F. (1970). Byssinosis in the textile industry. Archives of Environmental Health, 21, 475-478.

Central Agency for Public Mobilization and Statistics (1974). Statistical Handbook. Arab Republic of Egypt; Cairo.

Ciba Guest Symposium (1959). Terminology, definitions and classification of chronic pulmonary emphysema and related conditions. A report of the conclusions of the Ciba Guest Symposium. Thorax, 14, 286-299.

El Batawi, M. A. (1962). Byssinosis in the cotton industry of Egypt. British Journal of Industrial Medicine, 19, 126-130.

El Batawi, M. A. (1969). Respiratory diseases resulting from inhalation of cotton and other vegetable dusts: definition of byssinosis. In Proceedings of the XXIst International Congress on Occupational Health, Tokyo, 1969, pp. 168-170.

El Sobkey, M. A. (1975). MD thesis, Faculty of Medicine, Cairo University.

Mair, A., Smith, D. H., Wilson, W. A., and Lockhart, W. (1960). Dust diseases in Dundee textile workers. British Journal of Industrial Medicine, 17, 272-278.

Popa, V., Gavrilescu, N., Preda, N., Teculescu, D., Plecias, M., and Cristea, M. (1969). An investigation of allergy in byssinosis sensitisation to cotton, hemp, flax and jute antigens. British Journal of Industrial Medicine, 26, 101-108.

Roach, S. A., and Schilling, R. S. F. (1960). A clinical and environmental study of byssinosis in the Lancashire cotton industry. British Journal of Industrial Medicine, 17, 1-9.

Schilling, R.S. F. (1956). Byssinosis in cotton and other textile workers. Lancet, 2, 319-324.

Schilling, R. S. F., Vigliani, E. C., Lammers, B., Valić, F., and Gilson, J. C. (1964). A report on a conference on byssinosis. In Proceedings of the XIVth International Congress on Occupational Health, Madrid, 1963, vol. 2, pp. 137-145. Excerpta Medica Foundation: Amsterdam.

Siddhu, C. M. S., Nath, K., and Mehrotra, R. K. (1966). Byssinosis amongst cotton and jute workers in Kanpur. Indian Journal of Medical Research, 54, 980-994.

Smith, G. F., Coles, G. V., Schilling, R. S. F., and Walford, J. (1969). A study of rope workers exposed to hemp and fiax. British Journal of Industrial Medicine, 26, 109-114.

Taylor, G., and Massoud, A. A. E. (1968). Byssinosis. In Recent Advances in Clinical Pathology, pp. 465-474. Edited by S. C. Dyke. J. \& A. Churchill Ltd: London.

Valic, F. and Žuskin, E. (1971). A comparative study of respiratory function in female non-smoking cotton and jute workers. British Journal of Industrial Medicine, 28, 364368.

Valić, F. and Žuškin, E. (1972). Effects of different vegetable dust exposures. British Journal of Industrial Medicine, 29, 293-297.

Valić, F., Žuškin, E., Walford, J., Keršić, W., and Pauković, R. (1968). Byssinosis, chronic bronchitis, and ventilatory capacities in workers exposed to soft hemp dust. British Journal of Industrial Medicine, 25, 176-186.

Žuškin, E. and Valić, F. (1973). Respiratory response in simultaneous exposure to flax and hemp dust. British Journal of Industrial Medicine, 30, 375-380. 